\title{
Food Insecurity: Does It Push Married Women to Participate in Labor Force?
}

\author{
Ririn Kuncaraning Sari ${ }^{1}$ and Dwy Bagus Cahyono ${ }^{2}$
}

\begin{abstract}
Women's labor force participation in Indonesia tends to be lower than men. In married women, decisions to participate in labor force are more complicated related to their duties at home. Economic difficulties is one of the reason for their participation. This research aims to look the relationship of household food insecurity that illustrates the economic difficulties and material hardship of the family to the woman labor force participation. Using 2017 Susenas survey, this paper assesed food insecurity from Food Insecurity Experience Scale (FIES). The results show that labor force participation in married women is 50,05 percent where most of the married women work in informal sector $(60,31$ percent). However, probit regression shows that tendencies of married women to participate into labor market higher with the severity of the food insecurity. Married women who experience severe food insecurity 6,3 point percent more likely to participate in the labor force than the one who has food security. But overall, education, husband's working status and type of residence are the strongest determinant of married women labor force participation.
\end{abstract}

Keywords — labor force, FIES, Susenas, probit regression.

\section{INTRODUCTION}

Indonesia's National Labor Force Survey (SAKERNAS) 2017 showed that men's labor force participation is higher $(82,5 \%)$ than women's $(50,89 \%)$ [1]. Women's labor force participation number has also tended to be low and stagnant over last two decades (Figure 1). Labor Force Participation Rate (TPAK) is an indicator that determines the size and composition of a country's resources. Therefore, can be used to see the supply of labor in the future. Asian Developement Bank (ADB) claim that increasing women labor force participation could change the Indonesia's economy pattern [2] and employment of woman especially a married woman tend to increase their child and family welfare [3], [4]. However, women's decision on entering labor market is more complicated than the men's. Two reasons explaining the low number of women labor force participation is firstly because they are can counting on the husband's salary and the second one is because they will have lesser time on taking care their children [5].

Data in Figure 1 show a tendency of married women to choose informal job. A research using Indonesia's National Economy Social Survey (SUSENAS) 2012, showed that in every decile of expenditure, percentage of women working on informal job is higher than men -

\footnotetext{
${ }^{1}$ Ririn Kuncaraning Sari, Departement of Economic and Business, Universitas Indonesia, Depok, Indonesia. E-mail: ririn.kuncaraning@gmail.com

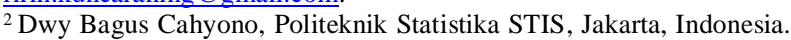
E-mail: dwy.bagus.cahyono@yahoo.com
}

about $64,34 \%$ versus $55,92 \%$. This matter is related to flexibility of working hours and women will have more time to take care their children [6]. Despite the advantages, working on informal job have tendencies to low productivity, low income, no insurance, low job stability and more risk in their job [7]. That means more possibility for married women are working on nondecent job.

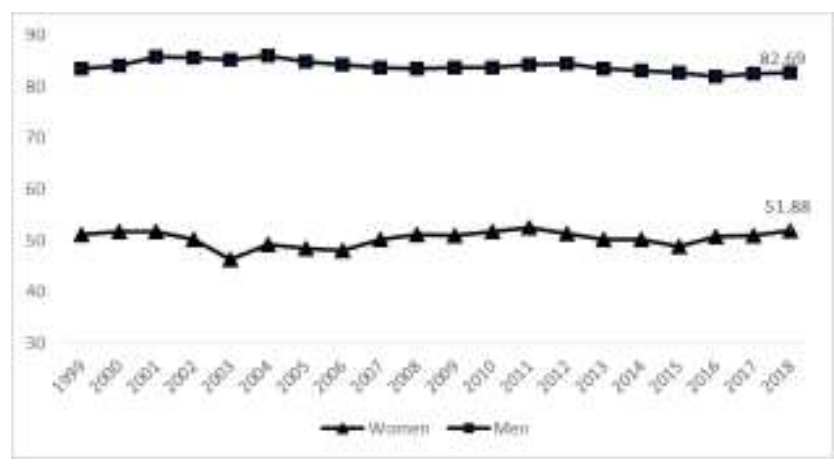

Figure 1. Labor Force Participation Rate by Sex in Indonesia, 19992018

Source: BPS

Decision of a person to take a job depends on the nonlabor income they received [8]. The higher income of the husband or family, will has a positive effect to leisure time and negatively affect the working hours. The bigger income will decrease married women labor force participation [9]. On the other hand, the more difficult family's economy status, the more likely a married woman to get into the labor market [10]-[12]. Eventhough, research using quintile expenditure percapita as a proxy for household's income in Indonesia showing an inversely result. The higher household expenditure percapita increase probability married women to enter the labor force [13].

Material hardship is a way to see economic difficulties in the household. Material hardship had been used because poverty that caused by a low income represents only 14 percent of variation of problem dealt by a person [14]. Poverty (based on income) only represents someone's lack of money condition but actually, there is a worse condition in human's life related with the need's fulfillment [15]. Some proxy to show material hardship are food sufficiency, housing facility sufficiency and unmetneed medical examination [16], [17]. In order to represent material hardship, this research uses one of that indicator, that is food insecurity.

A person ecperience food indecurity when they haven't physical, social and economic access to sufficient safe and nutritious foods that meet their dietary needs and 
food preferences for active and healthy life [18]. Food insecurity in the material hardship is one of indicators that represent an inability on fulfilling the basic daily needs [19]. Based by Indonesia's Food Security Agency using nutritional adequacy rate $(<90 \%$ AKB) the percentage of Indonesian on heavy-food-insecurity and medium-food-insecurity condition are about 39,85 percent on total in 2016 [20]. This means over one third of Indonesian are on food insecurity condition. Compared to 2016th poverty rate in March 2016 which is $10,86 \%$ [21], percentage of Indonesian with food insecurity status are far higher that government should give more attention on this problem.

Many studies found that household's economy status affect the labor force participation of married women. They use various approach to show household's economic status such as husband's education, husband's job, husband's income and house facilities [10][11], household expenditure [13] and household's poverty [22]. But still limited research that uses material hardship dealt by a family. This research aims to dive deeper to better understand how food insecurity as one indicator to show material hardship affect married-women's labor force participation. Using different economic approach, the research goals is to fill the gap for researching determinant of married-women labor force participation in Indonesia.

\section{METHOD}

The analysis is based on the data collected from National Expenditure Survey (SUSENAS) in 2017 that was held by Badan Pusat Statistik (BPS) Indonesia. The survey covered 300.000 household in Indonesia which were conducted every March. The unit analysis is married women aged 15-49 years old that the status in the household is wife. After filtering, there was 165.060 sample which is egligible with this research.

Labor force is both persons who are employed and unemployed [23]. Employment concept using here is the one that BPS use as well. It compromprises all persons of working age who during the past week (refers to survey period) doing an economic activity with the intention of obtaining or assisting in obtaining income or profits at least one hour (without breaking up) [24]. Were in the following categories is paid employment (whether at work or with a job but not at work) and self-employment (whether at work or with an enterprise but not at work). While unemployed compromise all persons of working age who were without work during a week (not in paid employment or self emplyment), currently available for work, and seeking work [23].

This research aim to see the effect of material hardship by food insecurity indicators. Food insecurity was assesed with Food Insecurity Experience Scale (FIES). SUSENAS was adopted set of question (8 question) that have been developed by FAO. This questions sequentially shows worrying about how to produce food, compromising on quality and variety of food, reducing quantities, skipping meals and experiencing hunger [25]. Household with respons "No" in all of 8 questions classified as food secure, household with responds "Yes" in one or all of the first three questions classified as mild food insecurity, household with responds "Yes" in one or all of the $4^{\text {th }}-6^{\text {th }}$ questions classified as moderate food insecurity and the last, household with responds "Yes" in one or all of the two last questions classified as severe food insecurity.

In this research, probit regression is being used to research the relationship between food insecurity and married women's labor force participation. In probit model, married women's labor force participation is the dependent variable with binary values, 1 if married women was in the labor force and 0 if otherwise. The probability to entering labor force is the function of:

$\operatorname{Pr}(\mathrm{y}=1 \mid \mathrm{x})=\beta_{0}+\beta_{1} F S 1+$

$$
\begin{aligned}
& \beta_{2} F S 2+\beta_{3} F S 3+\beta_{4} A G E_{-} W+\beta_{5} E D U C_{-} W 1+ \\
& \beta_{6} E D U C_{-} W 2+\beta_{7} C H I L D+\beta_{8} E D U C_{-} H B 1+ \\
& \beta_{9} E D U C_{-} H B 2+ \\
& \beta_{10} L F P_{-} H B+\beta_{11} E C O N 1+\beta_{12} E C O N 2+\beta_{13} R E S+ \\
& \varepsilon
\end{aligned}
$$

Where FS is food security status (food secure (reference), mild food insecurity, moderate food insecurity, severe food security), AGE_W is married woman's age, EDUC_W is the last education completed by married woman (elementary school and below (reference), graduate high school and graduate college), CHILD is group of number of children (two and below (reference), more than two), EDUC_HB is the last education completed by husband (elementary school and below (reference), graduate high school and graduate college), LFP_HB is husband's participation in the labor force (not participate in labor force (reference), participate in labor force), ECON is group of household expenditure (20\% highest (reference), $40 \%$ middle, $20 \%$ lowest), and RES is type of residence (rural (reference), urban).

Marginal effect was use to interperate the probability of married women to enter the labor force. Whereas the hypothesis in this research is that food insecurity has a positive effect on the tendency of married women to enter the labor force. The more severe food insecurity experienced by households, the married woman will have a higher probability of participating in the labor force.

\section{RESUlts AND Discussion}

\section{A. Description of Overall Labor Force Participation in Indonesia Based on SUSENAS 2017}

Based on SUSENAS 2017 (Figure 2), labor force participation in Indonesia is 66,53 percent (Table 2). The value is slightly fewer than labor force participation based on SAKERNAS 2017's August data (66,67 percent) [1] which is officially statistic of labor force participation rate produce by BPS. Based on gender, men's labor force participation is higher (83,67 percent) than women's (49,46 percent). Based on marital status, men's labor force participation is dominated by those who have married $(93,95$ percent), whereas the biggest contributor of women's labor force participation are divorced women. This is reasonable to see divorced women that they will be the backbone of the family to support their children. Whereas married women are probably got income from their husband, labor force participation is as lower as 51,05 percent. There is also a fact that both men and women unmarried status prefer 
working in the formal sector than informal sector. People who have marriage or divorce status are tend to choose the informal sector. The value is even greater for women. In marital status, the tendency of women to work in the informal sector is 65,61 percent.

By the area of residence, both men and women, labor force participation is higher in urban areas compared to rural. In urban areas both men and women prefer to work in the formal sector whereas in rural areas otherwise. By the education, both male and female labor force participation is highest in the hishest level of education. However, those with low education tend to work in the informal sector when compared to those with higher education who mostly work in the formal sector.

Person's poverty status can be used to determine the family's economic status. Poverty is obtained by comparing the poverty line per family with the basic poverty line which is calculated based on the type of regions and provinces in Indonesia. Data shows that the labor force participation for both men and women in Indonesia is higher in non-poor conditions when compared to poor conditions. The data also shows that poor people are more likely to work in the informal sector. By household food security, the data shws than for overall women, there are no significant diferencess on labor force participation.

\section{B. Sample Description}

Sample from SUSENAS 2017 shows that the proportion of married women aged 15-49 years old and the status in the house hold is wife who are in labor force is 56,7 percent. The distribution of samples by type of region is quite evenly equal to 52,20 percent in rural areas and 47,80 percent in urban areas. Based on age, the highest proportion of married women is at the age of 40 years and over, while based on level of education, the highest are elementary school graduates and the lowest are university graduates. The number of samples who has two children or less are 64,46 percent. Meanwhile, based on characteristics of the husband, he largest is the sample that has a husband who works and has an elementary school education.

Based on economic status, it can be seen that the sample that is categorized as poor is 8,74 percent. Whereas based on food insecurity, it can be seen if the sample that experiences low food insecurity is 16,79 percent, who experiences medium food insecurity by 6,43 percent and who experiences severe food insecurity by 3,19 percent.

\section{Married Women's Labor Force Participation (Based on Sample)}

Figure 3 shows married women's labor force participation by characteristic. According to Figure 2, labor force participation of married women in Indonesia is 51,05 percent. By the residence area, the sample of married women in rural areas have higher labor force participation than the urban one. While by ages labor force participation tends to increase until the age of 4549 years. Based on education, the pattern of labor force

\begin{tabular}{|c|c|c|}
\hline \multicolumn{2}{|c|}{ Characteristic } & \multirow{2}{*}{$\begin{array}{l}\text { Percentage } \\
(\%)\end{array}$} \\
\hline Labor Force & In the Labor force & \\
\hline Participation & Not in the labor force & 43.3 \\
\hline \multirow{2}{*}{ Type of residence } & Urban & 52.2 \\
\hline & Rural & 47.80 \\
\hline \multirow{3}{*}{$\begin{array}{l}\text { Married woman's } \\
\text { age group }\end{array}$} & $15-24$ & 7.199 \\
\hline & $25-39$ & 34.131 \\
\hline & $40-49$ & 58.671 \\
\hline \multirow{7}{*}{$\begin{array}{l}\text { Married woman's } \\
\text { age education }\end{array}$} & $\begin{array}{l}\text { Never attending } \\
\text { school/Not graduated } \\
\text { elementary }\end{array}$ & $\begin{array}{l}10.909 \\
32.974\end{array}$ \\
\hline & Graduated elementary & 22.655 \\
\hline & Graduated Junior High & 24.743 \\
\hline & School & 8.719 \\
\hline & Graduated Senior High & \\
\hline & School & \\
\hline & Graduated College & \\
\hline \multirow{5}{*}{$\begin{array}{l}\text { Number of } \\
\text { children } \\
\text { Husband's labor } \\
\text { force participation }\end{array}$} & 2 and below & 64.456 \\
\hline & More than 2 & 35.544 \\
\hline & Not working & 1.448 \\
\hline & Working & 98.552 \\
\hline & Never attending & \\
\hline \multirow{8}{*}{$\begin{array}{l}\text { Husband's } \\
\text { education }\end{array}$} & school/Not graduated & 11.750 \\
\hline & elementary & 30.752 \\
\hline & Graduated elementary & 19.354 \\
\hline & Graduated Junior High & 29.298 \\
\hline & School & 8.847 \\
\hline & Graduated Senior High & \\
\hline & School & \\
\hline & Graduated College & \\
\hline \multirow{2}{*}{ Poverty status } & Not poor & 91.257 \\
\hline & Poor & 8.743 \\
\hline \multirow{5}{*}{$\begin{array}{l}\text { Food insecurity } \\
\text { status }\end{array}$} & Food secure & 73.590 \\
\hline & Mild food insecurity & 16.787 \\
\hline & Moderate food insecurity & 6.429 \\
\hline & Severe food insecurity & 3.193 \\
\hline & Total & 100 \\
\hline
\end{tabular}

Source: Computed by author based on 2017 Susenas

participation of married women in the form of the letter $J$, where high labor force participation in low education (not completing school) then decreases at the level of primary and secondary education and it increases again in university graduates, similar results were also found in research [11]. Meanwhile, labor force participation of married women more children (more than two) is lower than those who have less children (two or less).

By poverty status, married women with poor status are less likely to enter the labor market, by 48,39 percent and 52,69 percent of non-poor women who actually participate in the labor market. Meanwhile, by food insecurity, married women who have food secure status have the highest labor force participation. However, more than half married women who experienced food insecurity tend to join the labor market.

Figure 4 shows that a married woman classified as working are more likely to work in the informal sector on most of the characteristics, except the woman with high education profile (graduated university). The percentage of women in rural areas who work in the informal sector is higher than in urban areas. Meanwhile, by age, the higher the age, the higher the percentage of working in the informal sector. The lower the education of married women, the higher the percentage of working in the informal sector. By economic status, those with low economic status and experiencing food insecurity are more likely to work in the informal sector. 
Probit result (Table 2) shows that food insecurity positive and significantly influences the labor force participation of married women. Married women who experience mild food insecurity are 2 point percent more likely to participate in the labor force than married women in food secure household. Whereas married women who experience severe food insecurity are 6,3 point percent more likely to participate in the labor force than married women in food secure household. However, this result support our hypothesis that the more material hardship that experience in the household would increasing the labor force participation of married women. This result was similar with the research in America showing that material hardship in the household makes a mother be more likely to enter the labor market even though she can rely on social protection by the government [26]. Moreover, food insecurity that associated with low level of health status especially for children can be one of the reasons that push married women to work. Previous paper that summarize the effect of food insecurity to health outcome shows that based on the research, compared to children in food secure household, children in food insecure household had 2-3 times higher odds of having anemia, 1,4-2,6 times higher odds of having asthma and 2 times higher odds of having fair or poor health [27].

Married women's age has positive and significant effect though the effect is low. Women in the age over 40 years old have higher tendency to participate in the labor force compared to the younger because their dependents on raising children have diminished (the children already grown up) [11]. Whereas education show a mixed result. Compared with married women who's the education is elementary and below, graduated high school have significant negative effect on labor force participation. One of the reason for this is because women who graduated from high school (junior and senior) unwilling to work in blue collar job, yet they don't have enough ability to compete in getting white collar job [13]. But for women who graduated from college has probability for participate the labor force 27,4 point percent higher than who has education in elementary or below. High education will increase the opportunity cost to not entering labor force because the time and cost for research for completing education is high [28]. High education also increasing the productivity, in order that encourage-even married women- to participate in labor force [9]. Previous research shows the same result that education will increase married women labor force participation [10], [12], [29].

Children in terms of numbers, and at a young age are known to reduce the chances of married women to enter the labor market [7], [13], [22]. The result in this research shows similar result, that number of children is significant and negatively affected married women labor force participation. Although, the probability of having more than 2 children slightly decrease the probability of entering the labor force by 1,1 point percent. This low impact might be happened because in Indonesia nowadays the childcare institution (day care, full day school etc.) began to emerge.
Husband's characteristic can be used to show household economic condition [10]. The probability of married women to join the labor force was negatively associated with graduated high school and college husband compared to husband with elementary and below education. Husband that graduated from college decreases the probability of married woman to enter labor force by 5,7 point percent compared to husband with elementary and below education. This result suggests that with higher education, husband could have higher potential earning that allow wives to not participating in labor market. The husband's labor force status shows similar pattern as well. Husband that are working, seeking job or temporary leave from job decreases the probability of married women's labor force by 10.4 percent point.

TABLE 2. PROBIT ESTIMATES FOR MARRIED WOMEN

\begin{tabular}{|c|c|c|c|}
\hline Variables & Coefficient & $\begin{array}{c}\text { S.E } \\
(\mathrm{t}- \\
\text { statistics) }\end{array}$ & $\begin{array}{l}\text { Marginal } \\
\text { effects } \\
(\mathrm{dydx})\end{array}$ \\
\hline \multicolumn{4}{|l|}{$\begin{array}{l}\text { Household Food } \\
\text { insecurity: }\end{array}$} \\
\hline Food secure & 0,051 & $0,0085 * * *$ & 0,019 \\
\hline Mild food insecurity & 0,168 & $0,0132 * * *$ & 0,0629 \\
\hline $\begin{array}{l}\text { Moderate food } \\
\text { insecurity }\end{array}$ & 0,169 & $0,0175^{* * *}$ & 0,063 \\
\hline $\begin{array}{l}\text { Severe food } \\
\text { insecurity }\end{array}$ & & & \\
\hline \multicolumn{4}{|l|}{ Woman } \\
\hline $\begin{array}{l}\text { Characteristics: } \\
\text { Age }\end{array}$ & 0,024 & $0,0005^{* * *}$ & 0,01 \\
\hline \multicolumn{4}{|l|}{ Education: } \\
\hline $\begin{array}{l}\text { Elementary school } \\
\text { and below }\end{array}$ & $\begin{array}{l}-0,039 \\
0,816\end{array}$ & $0,008 * * * *$ & $-0,0155$ \\
\hline $\begin{array}{l}\text { Graduated High } \\
\text { School }\end{array}$ & & & \\
\hline Graduate college & $-0,0294$ & $0,007 * * *$ & $-0,011$ \\
\hline \multicolumn{4}{|l|}{ Number of children: } \\
\hline \multicolumn{4}{|l|}{ More than 2} \\
\hline \multirow{2}{*}{\multicolumn{4}{|c|}{ Husband's }} \\
\hline \multicolumn{3}{|l|}{ Characteristics: } & \\
\hline \multicolumn{4}{|l|}{ Education: } \\
\hline Elementary school & $\begin{array}{l}-0,037 \\
-0152\end{array}$ & $\begin{array}{l}0,008 * * * \\
0,015 * * *\end{array}$ & $\begin{array}{l}-0,014 \\
-0,057\end{array}$ \\
\hline \multicolumn{4}{|l|}{ Graduated High } \\
\hline Graduate college & $-0,285$ & $0,029 * * *$ & $-0,104$ \\
\hline \multicolumn{4}{|l|}{ Labor Force } \\
\hline \multicolumn{4}{|l|}{ Participation: } \\
\hline \multicolumn{4}{|l|}{ Not working } \\
\hline \multicolumn{4}{|l|}{ Working } \\
\hline \multicolumn{4}{|l|}{$\begin{array}{l}\text { Family expenditure per } \\
\text { capita: }\end{array}$} \\
\hline $20 \%$ highest & $-0,0655$ & $0,0101 * * *$ & $-0,0245$ \\
\hline $40 \%$ middle & $-0,105$ & $0,0108 * * *$ & $-0,0397$ \\
\hline $40 \%$ lowest & & & \\
\hline \multicolumn{4}{|l|}{ Type of residence } \\
\hline Rural & & & \\
\hline Urban & $-0,2$ & $0,0073 * * *$ & $-0,0755$ \\
\hline Constanta & $-0,286$ & $0,0367 * * * *$ & \\
\hline
\end{tabular}

Note: *** indicated significant at $5 \%$ level

Source: Computed by author based on 2017 Susenas

Household expenditure have significant and negative effect to married women's labor force participation. This result is interesting because this sign was contradicting with theory. Married women from 40\% lowest expenditure household have decreasing probability for entering labor force by 4 point percent compared to 
married women in $20 \%$ highest expenditure (richest group of household by expenditure). This might be happend becouse women from the highest economic group need self-actualization after having a high level of education so they tend to enter the labor market [30]. Living in urban areas have significant and negative effect for married women's labor force participation. Compared to living in rural areas, married women who lives in urban areas will decrease probability of entering labor force by 7,5 point percent. This result suggests that in rural area, there are more flexible working hours than the urban related to the distance of the office, traffic, and abundance of informal employment especially in agricultural sector.

\section{E. Conclucions and Suggestions}

Married women who experienced food insecurity have a higher probability to enter the labor force. In line with the statement, higher education, older age, living in the village increases the chances of married women entering the labor force as well. Contrariwise more children, high educated husband and working husband tend to reduce the labor force participation of married women.

Increasing women's labor force participation is related to women's empowerment which will affect gender equality in politics, rejection of violence and household decision making. This research suggests that food insecurity forces married women labor force participation and by the descriptive analysis, there are tendency that they are more likely to work in informal sector. The informal sector itself is known have many shortcomings because it doesn't cover employee protection and is full of uncertainty. Due to that reason, the government needs to provide job and entrepreneurship training for married women who experience food insecurity. This effort has to be done so that women in this group could have more working skills in the future and they can bring their families out of food insecurity while increase labor force participation. Furthermore to encourage married women's labor force participation, policies that encourage women to have higher education need to be implemented as well.

\section{REFERENCES}

[1] Badan Pusat Statistik, Indikator Pasar tenaga kerja Indonesia 2017. Jakarta: BPS, 2017.

[2] S. Schaner and S. Das, "Female Labor Force Participation in Asia: Indonesia Country Study," Manila, 2016.

[3] J. Pahl, "The allocation of money and the structuring of inequality within marriage," Sociol. Rev., vol. 31, no. 2, pp. $237-$ 262, 1983.

[4] L. Haddad, "The income earned by women: Impacts on welfare outcomes," Agric. Econ., vol. 20, no. 2, pp. 135-141, 1999.

[5] G. Standing and G. Sheehan, Labor Force Participation in Low Income Countries. Geneva: ILO.

[6] J. Priebe, F. Howell, and V. A. Sari, "Poverty and The Labour Market in Indonesia: Employment Trends Across the Wealth Distribution," Jakarta, 2014.

[7] AIPEG, DFAT, and CDES, "Women's Economic Participation in Indonesia," Jakarta, 2007.

[8] G. J. Borjas, Labor Economics, Seventh Ed., vol. 113, no. 4. United States: Mc Graw Hill Education, 2016.

[9] J. Mincer, Labor Force Participation of Married Women: A Study of Labor Supply, vol. 1, no. 06. Princeton University Press,
1962.

[10] D. Widarti, "Determinants of labour force participation by married women: the case of Jakarta," Bull. Indones. Econ. Stud., vol. 34, no. 2, pp. 93-120, 1998.

[11] O. Keiichi and M. Akter, "Female Labor Force Participation in Indonesia,” J. Int. Coop. Stud., vol. 14, no. 3, pp. 71-108, 2007.

[12] R. Ismail and N. Sulaiman, "Married women labor supply decision in Malaysia," Asian Soc. Sci., vol. 10, no. 3, pp. 221231, 2014.

[13] F. Melati, "Partisipasi Angkatan Kerja Perempuan Menikah di Indonesia : 1979-2017," Universitas Indonesia, 2018.

[14] S. E. Mayer and C. Jencks, "Poverty and the Distribution of Material Hardship," J. Hum. Resour., vol. 24, no. 1, p. 88, 1989.

[15] J. Iceland and K. J. Bauman, "Income poverty and material hardship: How strong is the association?," J. Socio. Econ., vol. 36, no. 3, pp. 376-396, 2007.

[16] H. Boushey and B. Gundersen, "When Work Just Isn't Enough: Measuring Hardship Faced by Families After Moving from Welfare to Work," Washington D.C, 202/775-8810, 2001.

[17] J. X. Sullivan, L. Turner, and S. Danziger, "The relationship between income and material hardship," J. Policy Anal. Manag., vol. 27 , no. 1, pp. 63-81, 2008.

[18] Food and Agriculture Organization of the United Nations, The State of Food Insecurity in the World Addressing food insecurity in protracted crises 2010 Key messages. 2010.

[19] S. G. Beverly, "Measures of material hardship: Rationale and recommendations," J. Poverty, vol. 5, no. 1, pp. 23-41, 2001.

[20] Badan Ketahanan Pangan, Statistik Ketahanan Pangan 2018. Jakarta: BKP, 2019.

[21] Badan Pusat Statistik, Indikator Kesejahteraan Rakyat 2016. Jakarta: BPS, 2016.

[22] R. E. A. Khan and T. Khan, "Labor force participation of married women in Punjab (Pakistan)," Int. J. Soc. Econ., vol. 37, no. 8, pp. 592-612, 2010.

[23] ILO, Measuring the Economically Active in Population Censuses: A Handbook. New York: United Nations, 2010.

[24] BPS, "Konsep/Penjelasan Teknis Mengenai Ketenagakerjaan." [Online]. Available: https://bps.go.id/subject/6/tenagakerja.html\#subjekViewTab1. [Accessed: 28-Oct-2019].

[25] T. Ballard, A. Kepple, and C. Cafiero, "The food insecurity experience scale: development of a global standard for monitoring hunger worldwide," Tech. Pap., no. October, pp. 1$16,2013$.

[26] K. J. Bauman, "Welfare, Work and Material Hardship in Single Parent and Other Household," J. Poverty, vol. 6, no. 1, pp. 2141, 2002.

[27] C. Gundersen and J. P. Ziliak, "Food Insecurity and Health Outcomes," Health Aff., vol. 34, no. 11, pp. 1830-1839, 2015.

[28] M. Qinfen, "2017 Female Labor Force Participation in Malaysia : Time-Series," South East Asia J. Contemp. Business, Econ. Law, vol. 14, no. 3, pp. 1-7, 2017.

[29] S. Schaner and S. Das, "Female Labor Force Participation in Asia: Indonesia Country Study," SSRN Electron. J., no. 474, 2016.

[30] I. Gaddis and S. Klasen, "Economic Development, Structural Change, and Women's Labor Force Participation: A Reexamination of the Feminization U Hypothesis," J. Popul. Econ., vol. 27, no. 3, pp. 639-681, 2014. 
IPTEK Journal of Proceedings Series No. 6 (2019), ISSN (2354-6026)

The $1^{\text {st }}$ International Conference on Global Development - ICODEV

November $19^{\text {th }}, 2019$, Rectorate Building, ITS Campus, Sukolilo, Surabaya, Indonesia

FIGURE 2. LABOR FORCE PARTICIPATION BY CHARACTERISTIC AND SEX, 2017

\begin{tabular}{|c|c|c|c|c|c|c|c|c|c|}
\hline \multirow{3}{*}{ Characteristic } & \multicolumn{3}{|c|}{ Man } & \multicolumn{3}{|c|}{ Woman } & \multicolumn{3}{|c|}{ Total } \\
\hline & \multirow{2}{*}{$\begin{array}{l}\text { Laboe force } \\
\text { participation }\end{array}$} & \multicolumn{2}{|c|}{ Working } & \multirow{2}{*}{$\begin{array}{l}\text { Labor force } \\
\text { participation }\end{array}$} & \multicolumn{2}{|c|}{ Working } & \multirow{2}{*}{$\begin{array}{l}\text { Labor force } \\
\text { participacion }\end{array}$} & \multicolumn{2}{|c|}{ Working } \\
\hline & & Informal & Formal & & Informal & F ormal & & Informal & Fornal \\
\hline \multicolumn{10}{|l|}{ Marital status } \\
\hline Single & 62.61 & 40.91 & 59.09 & 43.35 & 24.01 & 75.99 & 35.04 & 35.82 & 64.18 \\
\hline Married & 93.95 & 55.01 & 44.99 & 51.05 & 65.61 & 34.39 & 7235 & 58.77 & 41.23 \\
\hline Divorced & 87.81 & 55.52 & 44.48 & 73.83 & 52.49 & 47.51 & 78.78 & 53.69 & 46.31 \\
\hline Widowed & 60.46 & 73.15 & 26.85 & 43.91 & 76.78 & 23.22 & 47.19 & 75.86 & 24.14 \\
\hline \multicolumn{10}{|l|}{ Type of region } \\
\hline Riral & 81.59 & 38.63 & 6137 & 48.13 & 45.33 & 54.67 & 64.83 & 41.13 & 58.87 \\
\hline Urban & 86.08 & 67.61 & 32.39 & 51.00 & 76.35 & 23.65 & 68.50 & 70.86 & 29.14 \\
\hline \multicolumn{10}{|l|}{ Edecation } \\
\hline Not sehool/ not finished elementary & 83.73 & 73.23 & 26.77 & 50,03 & 80.80 & 19.20 & 6421 & 76.66 & 23,34 \\
\hline graduated from elementary & 85.58 & 67.46 & 32.54 & 48.34 & 75.89 & 24.11 & 66.78 & 70.55 & 29.45 \\
\hline graduared from junior high school & 71.73 & 54.92 & 45.08 & 37.79 & 63.60 & 36.40 & 54.82 & 57.89 & 42.11 \\
\hline graduated from senior high school & 88.59 & 36.58 & 63.42 & $\$ 1.17$ & 46.01 & 53.99 & 7197 & 39.53 & 60.47 \\
\hline graduxred university & 92.33 & 1692 & 83.08 & 77.83 & 13.19 & 86.81 & 84.96 & 15.19 & 84.81 \\
\hline \multicolumn{10}{|l|}{ Poverty status: } \\
\hline Not poot & 8381 & 50.77 & 49.23 & 49.87 & 58.51 & 41,49 & 66.87 & 53.65 & 46.35 \\
\hline Poor & 82.36 & 71.80 & 28.20 & 45.73 & 78.27 & 21.73 & 63.28 & 74.23 & 25.77 \\
\hline \multicolumn{10}{|l|}{ Food Insecurity } \\
\hline Food secure & 83.57 & 49.55 & 50.45 & 49.67 & 56.87 & 43.13 & 6657 & 52.29 & 47.71 \\
\hline Mild food insecurity & 84.86 & 61.56 & 38.44 & 49.18 & 70.76 & 29.24 & 6694 & 6494 & 35.06 \\
\hline Moderate food insecurity & 83.24 & 62.02 & 37,98 & 48.65 & 70.94 & 29.06 & 6595 & 65.32 & 34.68 \\
\hline Severe food insecurity & 81.20 & 58.75 & 41.25 & 47.79 & 66.03 & 33.97 & 6494 & 61.37 & 38.63 \\
\hline Total & 83.67 & 47.28 & 52.72 & 49.46 & 39.69 & 60.31 & 66.53 & 44.47 & 55.53 \\
\hline
\end{tabular}

Note: Classification of formal and informal job bassed on the status in the main job. Informal job comprise employers without worker/partner, employers with unpaid worker/partner, and family worker or unpaid worker. Whereas formal job comprise employers with paid worker/partner and employees.

Sumber: Computed by author based on 2017 Susenas

FIGURE 3. MARRIED WOMEN LABOR FORCE PARTICIPATION (AGE 15-49 YEAR OLD) BY CHARACTERISTIC, 2017

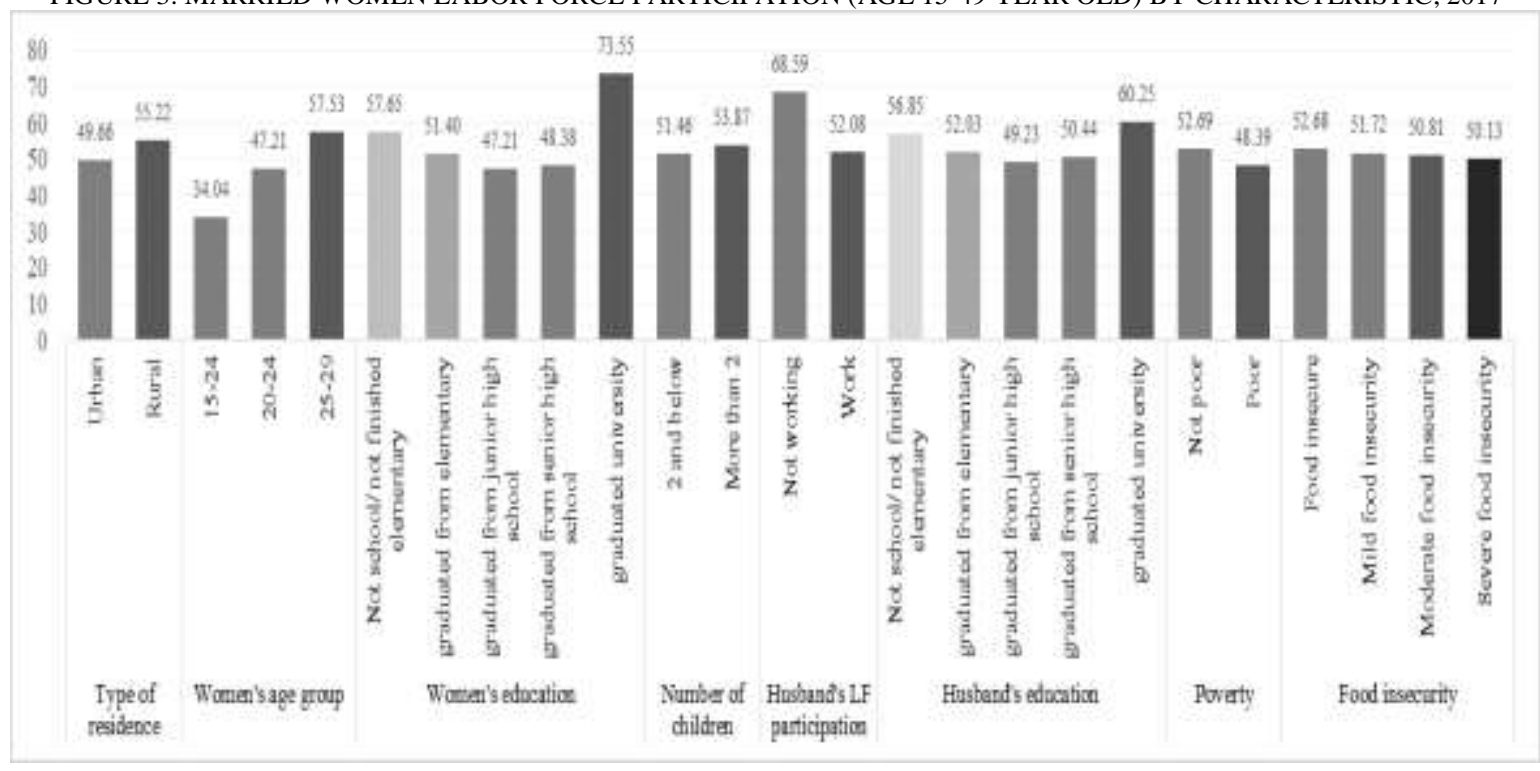

Source: Computed by author based on 2017 Susenas 


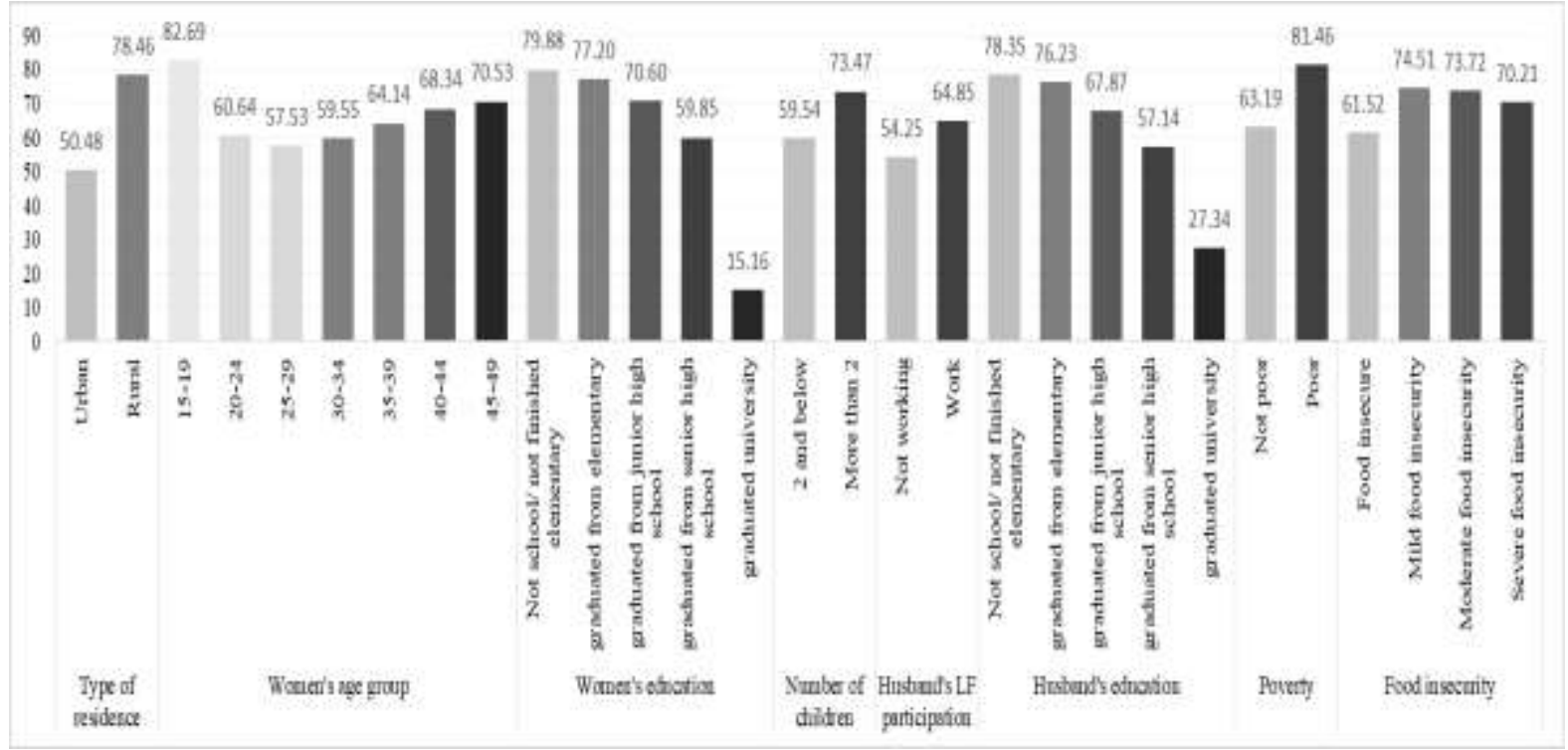

Source: Computed by author based on 2017 Susenas 